\title{
Life cycle cost analysis of a sustainable solar water distillation technique
}

\begin{abstract}
This paper presents a detailed estimation of the fabrication cost, water production cost (WC), and cost payback period (CPP) using annualized life cycle costing for a tubular solar still (TSS). The operation and maintenance cost (OM) and the number of sunny days in a year (d) have a significant effect on the WC. The WC is raised from 3.1 to $4.4 ¥ / \mathrm{L}$, if the OM increases from 5 to $18 \%$ of the capital cost, respectively. The WC is dropped by $35 \%$ (in average) when the $\mathrm{d}$ increases from 230 to 350 days. In addition, the CPP is greatly affected by the water selling prices and d. The CPP is dropped from 68 to 45 days due to the increase of $\mathrm{d}$ from 230 to 350 days (in average), respectively. The fabrication cost of the TSS (\$5) and the WC $(\$ 31 / \mathrm{m} 3)$ are affordable and much lower than the single-sloped passive solar still. Finally, it is revealed that the solar radiation is the most influential parameter on the productivity of TSS and a linear proportional relationship is found between them.
\end{abstract}

Keyword: Tubular solar still (TSS); Water cost; Life cycle cost; Payback period; Production; Solar radiation 